\title{
ASSISTED REPRODUCTION AND REPRODUCTIVE RIGHTS - COMPARATIVE ASPECTS BETWEEN REPUBLIC OF NORTH MACEDONIA AND REPUBLIC OF KOSOVO
}

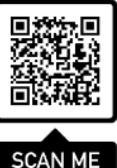

\author{
Prof. Ass. Dr. Arta SELMANI-BAKIU (i) 1* \\ Msc. Julinda ELEZI (ib) \\ 1 South East European University, Faculty of Law, arta.selmani@ seeu.edu.mk, *Correspondent Author \\ 2 South East European University, Faculty of Law, je17142@seeu.edu.mk
}

\begin{abstract}
Article history:
Submission 02 September 2020

Revision 04 November 2020

Accepted 23 December 2020

Available online 31 December 2020

\section{Keywords:}

Assisted Reproductive

Technology,

Reproductive Freedom and

Rights,

Family Planning.

A b s t r a c t

Developments in science and technology have, among other things, challenged the family. Human values, which change in step with this technological progress, have faced many legal, moral and ethical dilemmas which await answers from the science on bioethics. We are in such a situation when we discuss about many advances in contemporary and national family law, including new forms of family reproduction that differ from a natural process of child conceiving. The authors in this paper bring comparative aspects of biomedical and family legislation of the Republic of North Macedonia and Republic of Kosovo. Among other things, they emphasize that given the traditional and biological model of the family in our society, new reproductive forms are a very reserved topic in the family and biomedical field, but it awakens a curiosity of discussions on ethics, philosophy and legal regulation of reproduction of human beings in both countries. The numerous stereotypes that prevail in the society of both countries regarding the application of artificial reproduction technology methods are contrary to many legal and medical justifications for couples who do not have the opportunity to become parents in a biological (natural) way.
\end{abstract}

Therefore, the purpose of the authors is to provide accurate and grounded information through this text about the legal framework and medical options available to all persons who wish to exercise their reproductive right to establish a family.

\section{Introduction}

In the age of rapid development of science and technology, the family has not been left untouched, despite the fact that progress and reforms in family law are slower due to the culture, tradition, customs, the influence of religion and moral. Precisely because of these changes in the concept of parenthood and family, today it is very difficult to give the definition of the institution "family". The majority have an image of the "ideal family" consisting of biological mother, father and children, however, different reasons and circumstances have forced the change of this family model. Today we encounter different forms of family: single-parent families, remarriage and reconstituted families, extramarital families, same-sex families, families created by the new reproductive technologies. In terms of "destabilization" of the traditional family and the presentation of the contemporary pluralistic family, many questions and dilemmas arise in the reasons that have led to the definition of this new family model (Selmani - Bakiu, 2020).

In this article the authors want to inform the public that despite many obstacles in terms of changes in family processes, technology has played a very big role in terms of advancements in the forms of parenting establishing. Reproduction is no longer an issue which is beyond human control. What was once considered a natural process for conceiving a child, currently, is a conscious and planned transformation in human life in the moment when the one decides to take on the role of parent. In this regard, integral parts of contemporary birth policy are: artificial 
conception, in vitro fertilization, surrogate motherhood, childbirth by a single woman with donated genetic material, postmortem reproduction, conception of a child by three people and many other processes known from biomedical technology. Thus, today there is a wide range of opportunities for reproduction which have influenced the change the birth concept and the establishment of parenthood. Therefore, in a family macro plan there is no universal model of family planning which would be acceptable and appropriate for a legal system (Selmani-Bakiu, 2020).

Since the family legislations of the RNM and Kosovo are very similar, almost identical, the two countries have many differences in terms of incorporating some methods of artificial reproduction into their biomedical legislation. Therefore, the intention of the authors is through this paper to provide their references based on the right of reproduction in terms of family planning regulated by the Law on Biomedical Assisted Fertilization of RNM (BAF) and the Law on Reproductive Health of Kosovo. The authors in this paper bring the similarities as well as many differences in terms of types of methods for assisted biomedical reproduction, parental rights and legal status of children born through these methods. During their analysis, they come to concrete conclusions in terms of avoiding legal contradictions and filling legal gaps in the biomedical legislation of both countries, always concerning the best interest of children born through artificial reproduction technology.

\section{Reproductive Freedom through Biological, Artificial Birth and Refusal to Establish a Family}

The right for reproduction in the function of family planning and establishment is a right guaranteed and protected as a fundamental human right in the Universal Declaration of Human Rights (Article 16) and in the European Convention on Human Rights (Article 12). Parenting is one of the biggest transitions in the life roles of a man and a woman so it is very important in what form and by what methods they will establish their family. Furthermore, "Reproductive rights embrace certain human rights that are already recognized in national laws, international laws and others international human rights documents. These rights rest on the recognition of the basic rights of all couples and individuals to decide freely and responsibly the number, spacing and timing of their children and to have the information and means to do so, and the right to attain the highest standard of sexual and reproductive health. It also includes the right to make decisions concerning reproduction free of discrimination, coercion and violence, as expressed in human rights documents" (International Conference on Population and Development Programme of Action, 2014). The reproductive process is long, complex, and fraught with danger, especially for women. Successful reproduction requires men and women using conscious and unconscious strategies to give them the greatest chance of success. Successful reproduction is not a random event. It is a carefully calibrated system that has evolved through trial and error over the eons to provide for the greatest chance of human survival, that is, life. Life does not exist without successful reproduction and I believe successful reproduction is furthered by reproductive freedom. While reproductive freedom includes birth control or abortion, the ability to prevent or terminate a pregnancy is just one step in the process of creating life (Sanger, 2004).

An important change which brought the new era of human involvement in medical science, mainly in what was formerly considered the exclusivity of nature, was that the notion of "procreation" that was changed to the notion of "reproduction" which much less associates to the notion of reproduction. The difference between these two notions - "reproduction" which refers to the creation of children as laboratory products and the notion "procreation" which refers to the conception of children through sexual intercourse, announced in the beginning of in vitro procedures in everyday human life (Ramsey cited by Mickovik et al., 2016). According to this logic, assisted reproductive technology (ART) does not procreate children but only reproduces them. Therefore, the focus of the notion "reproduction" is in the interest of the rights of adults to "reproduce themselves", and not to create their own offspring (Ibid.). In this regard, it is important to emphasize that everyone can express their right to reproduction in two forms, both as a positive right to reproduction and a negative right to reproduction. The positive right to reproduction means the right of every person to have children and to become a parent. In this case, if this right cannot be exercised naturally, the interested person can exercise this right through medical treatment or through artificial insemination (Zendeli et al., 2020). On the other hand, the negative right to reproduction means the right of the person to decide not to be realized as a parent, i.e. to decide not to have children of his own. This right can be exercised in two ways, preventively and correctively. The preventive way is realized through education and contraception, respectively, sterilization, which can be temporary or permanent. In doing so, the person is free to decide which of the remedies allowed and recommended by medicine will be used. The corrective way of exercising the right not to have children is by applying the right to abortion, which is accepted and regulated in all European countries (Ibid.).

\subsection{Assisted Reproductive Technology}

From what was stated above, the person can realize the positive right to reproduction in a biological way through the natural process of childbirth, this right can also be realized in an artificial 
way through the application of technology methods of artificial reproduction. Therefore, all persons who want to have children, but due to some medical indications are prevented from being fulfilled as parents, biomedicine has enabled them the application of artificial reproduction technology.

The term "reproductive revolution" is not mere hyperbole. Most human reproduction will, of course, continue to occur as the result of sexual intercourse with only the technology of modern obstetrics involved. The major issues of human reproduction will remain access to prenatal and postnatal care, reduction of infant mortality, provision of adequate child care, and access to contraception and abortion (Robertson, 1994).

Assisted reproductive technology $(\mathrm{ART})^{1}$ is used to treat infertility. It includes fertility treatments that handle both a

\begin{abstract}
${ }^{1}$ In order to understand assisted reproduction and how it can help infertile couples, it is important to understand how conception takes place naturally. For traditional conception to occur, the man must ejaculate his semen, the uid containing the sperm, into the woman's vagina around the time of ovulation, when her ovary releases an egg. Ovulation is a complex event controlled by the pituitary gland, which is located at the base of the brain. e pituitary gland releases follicle-stimulating hormone (FSH), which stimulates follicles in one of the ovaries to begin growing. e follicle produces the hormone estrogen and contains a maturing egg. When an egg is mature, the pituitary gland sends a surge of luteinizing hormone $(\mathrm{LH})$ that causes the follicle to rupture and release (ovulate) a mature egg (Figure 1). To see the stages of embryo development. See more at American Society for Reproductive Medicine (2018). Regarding the Mitochondrial donation, a very important question is does the mitochondrial donor have any rights over the child? A woman who donates their eggs and/or embryos for use in other women's mitochondrial donation treatment will not be the genetic parent of the resulting child. This is because the mitochondria that they provide makes up less than $1 \%$ of the child's genetics. For this reason, they will not have any legal rights or responsibilities over the child and they remain anonymous. For more see at Human Fertilization and Embryology Authority:

https://www.hfea.gov.uk/treatments/embryo-testing-andtreatments-for-disease/mitochondrial-donation-treatment/
\end{abstract}

${ }^{2}$ Technological reproduction creates an environment of medical experimentation in which virtually anything can be tried on women's bodies. The claims that the technology is being perfected all the time camouflages the medicalized mutilation inherent in the procedures. In the medical literature, there is also a "violence of abstraction," where what is done to women is woman's egg and a man's sperm. It works by removing eggs from a woman's body ${ }^{2}$. The eggs are then mixed with sperm to make embryos. The embryos are then put back in the woman's body. In vitro fertilization (IVF) is the most common and effective type of ART. ART procedures sometimes use donor eggs, donor sperm, or previously frozen embryos. It may also involve a surrogate or gestational carrier. A surrogate is a woman who becomes pregnant with sperm from the male partner of the couple. A gestational carrier becomes pregnant with an egg from the female partner and the sperm from the male partner (American Society for Reproductive Technology, 2020). Types of methods for Artificial Reproduction are: in vitro fertilization (IVF), artificial insemination, posthumous reproduction, surrogacy, "three parents" technique, ${ }^{3}$ single mother by choice. ${ }^{4}$ These and many new methods which are constantly part of innovations in biomedical technology, have made it possible for infertile couples

encased in "numbers of pregnancies per laparoscopy" or "selective therapeutic termination of pregnancy." But women are not abstract, and neither are the mutilations inflicted on women's bodies (Raymond, 1993).

${ }^{3}$ These variants of IVF techniques would be used to prevent the transmission of maternally inherited mitochondrial DNA (mtDNA) disorders. Such disorders are incurable and may cause illness, disability and death. Neither 'maternal spindle transfers' (MST) nor 'pronuclear transfer' (PNT) has yet been used anywhere in the world to create children. Both techniques raise new legal, regulatory, ethical and social issues. See more at Riley, 2015.

${ }^{4}$ Medical technology is advancing at a more rapid rate than either layperson can comprehend or legal or ethical standards can address. Consider the developments in reproductive techniques. Years ago, when a woman wanted a baby, her options were readily defined. Now, with continual advancements in medical technology, her options have greatly increased. A woman desiring a child can, for example, be impregnated artificially. Such choices have their advantages and disadvantages. What influence, if any, should the doctor have in presenting these choices to the mother-to-be? Are there any problems for an offspring? Who should be involved in the decisions? Do state laws differ regarding such matters? Ambulatory health care employees need to be aware of the ethical and legal implications of such choices. Medical specialization means more people will be involved in personal health care. Managed care, policies, and providers will in part dictate how choices are made. If hospitalization is necessary, who is in charge, who coordinates, and who approves this care? Who decides the appropriate course of action in the case of conflicting medical opinions? Although specialization may enhance quality health care, it demands 
to become parents. In connection with these and many other similar issues, there is a need for family law to deal with the analysis of the legal implications of artificial reproduction, therefore as a result of the application of these methods for childbirth, family law needs to redefine legal notions of family and parenting law (Selmani-Bakiu, 2020). Furthermore, to appreciate the breadth and depth of the reproductive revolution, four aspects of that revolution are separately considered: (1) contraception and abortion; (2) treating infertility; (3) controlling the quality of offspring; and (4) using reproductive capacity for nonreproductive ends (Robertson, 1994).

\section{New Technologies for Artificial Reproduction as a way of Establishing a Family in the Biomedical Legislation of RNM}

Despite many changes in family legal relations which have imposed scientific and technological developments, the Law on Family of RNM since its adoption in 1992 has not undergone any substantial reform, despite the fact that in RNM, as in all other European countries, dynamic and profound changes have occurred in all segments of marital and family relations (Zendeli et al., 2020). A very important innovation that is in step with all contemporary concepts for starting a family, is the adoption of the Law on Biomedical Assisted Fertilization (BAF) in 2008 and the Law on Amendments to the Law on Biomedical Assisted Fertilization of 2014. With this law all the complex issues related to artificial reproduction technologies are regulated in detail. The Law on BAF regulates the process of artificial insemination, in vitro fertilization, posthumous reproduction, as well as the process of childbirth through a surrogate mother with the changes of 2014. The law regulates in detail some very important issues such as: the reasons for the implementation of BAF procedure; autologous fertilization ${ }^{5}$ and allogeneic fertilization; ${ }^{6}$ types of medical procedure; users of BAF rights; parental rights and user status; donation of genetic materials; realization of the BAF procedure; cryopreservation of genetic material and embryos; authorized health institutions for performing BAF; the role and powers of the State Commission for $\mathrm{BAF}$; state register for $\mathrm{BAF}$;

greater coordination for clients to benefit from it, and it increases the cost of medical care (Lewis \& Tamparo, 2007).

${ }^{5}$ According to Article 3 of the Law, the BAF procedure is performed if the previous treatment has been unsuccessful or the treatment with other methods is hopeless and in cases when the severe hereditary disease can be transmitted to the child. In implementing the BAF procedure, the legislator gives priority to the use of own genetic materials or embryos of potential parents (see article 6 of the Law BAF) oversight of the BAF procedure as well as criminal offenses in situations of abuse of rights by the BAF procedure. When applying assisted biomedical fertilization, the basic principle from which the Law on BAF starts is the observance of human rights and health standards. In this sense, it is envisaged that the implementation of the biomedical assisted fertilization procedure may be carried out in such a way as to ensure the protection of the human rights, dignity and privacy of the persons against whom the medical procedure is performed and the donors of sperm, eggs and embryos (Zendeli et al., 2020).

The main purpose why biomedical assisted fertilization is performed is to achieve fertilization in accordance with scientific and technical progress, science and medical experience with special emphasis on respect of human rights. According to Article 3 of the Law, the biomedical assisted fertilization procedure is performed if the previous treatment has been unsuccessful or the treatment with other methods is invisible and in cases when the severe hereditary disease can be transmitted to the child (Ibid). Law on BAF provides that as users of biomedical assisted fertilization can be adult and fully capable men and women, who are capable of exercising parental rights, who are married or living in an extramarital union. The right to use the BAF procedure is also available to adult women able to work who are not married or do not live in an extramarital union, if the previous treatment is unsuccessful, and who, according to their age and general health condition, are capable of parental care (Article 8). This means that the model of a contemporary birth rate policy is also the right of a single woman who decided not to marry but to become a parent with her to give birth and raise her only child, however it represents a kind of freedom of family planning (Selmani-Bakiu, 2016) In this regard, the law discriminates on the basis of gender, because this right is not provided for single men as an opportunity to establish a single-parent family. As can be seen, single women and extramarital spouses are the beneficiaries of BAF rights, but this category, including single men, is discriminated against the terms for use of surrogate motherhood which method is reserved only for married spouses (Ibid.).

\footnotetext{
${ }^{6}$ If in the BAF procedure the own genetic materials of the married or extramarital spouses is not possible to be used, namely, if they are not used in order to prevent the transmission of a serious inherited disease to children, then donated genetic materials or embryos from other persons can be used (Article 7 of the Law BAF).
} 
The Institute of "Surrogate Mother" is also an innovation in the family law and biomedical science of the RNM. Surrogacy, as a biomedical opportunity to solve the couple's infertility problem, was strictly prohibited by the Law on BAF of 2008, however in October 2014, the Parliament of the RM approved the "Law on Amendments to the Law on Biomedical Assisted Fertilization". This law provides a legal and medical solution for gaining parental rights for all those couples who biologically cannot have children (Selmani-Bakiu, 2016). Surrogacy represents the process of conceiving and giving birth to a child for ordering or legal parents by means of a preliminary agreement which has the effect of waiving the parental rights of the gestational mother. ${ }^{7}$ In fact, surrogacy enables married couples who cannot have children biologically, but who, for medical reasons, cannot use any of the methods for artificial fertilization, to have their own child, which will be carried and give birth by another woman. Depending on the possibility of fertilization with the genetic material of the legal parents, the born child is genetically related to one, both parents or neither of the parents (Zendeli at al., 2020). De iure surrogate motherhood as a method of establishing a family is in detail regulated by law and as a new opportunity for establishing a family for all those couples who refuse adoption as a legal/artificial way to become parents due to bureaucratic procedures in our country but also because they insist on having children with their genetic materials. However, despite the statutory and legal regulation of gaining parental rights through this biomedical method, many other issues are left to be discussed as well: psychological, ethical, and problems related to the mentality of our society to accept surrogacy as an opportunity to become a parent. Other aspects that are in constant discussion and debate are related to the theory on the sanctity of the natural process of pregnancy and the well-known Roman law principle Mater semper certa est (The mother is always certain) (SelmaniBakiu, 2016).

It is important to note that the RNM is one of the countries that legally regulates the posthumous reproduction by the Law on BAF of 2008. According to Article 33 of the Law on BAF "A husband and wife who according to medical indications or experiences in medical science are at risk of infertility for health reasons, within an authorized health institution and with their written statement may preserve their sperm, egg cells, or tissue from the ovary or testicles, for personal use. In the event of the

\footnotetext{
${ }^{7}$ A gestational mother is a woman "whose uterus was used for the nurturing and development of an embryo into a baby- according to the Medical Dictionary.

${ }^{8}$ According to Article 122 of the Inheritance Law Act, an heir might be just the person who is born alive at the time of the decedent's death or who has been conceived during the decedent's
}

death of the husband, assisted posthumous biomedical fertilization is permitted with his prior written consent, not later than one year after his death. Technological developments provide the opportunity for the child not only to be born, but also to be conceived after the death of one of the partners. Posthumous reproduction is a technology that enables conception and birth of a child after the death of one or both parents (Selmani-Bakiu, 2018).

It should be noted that this method is only possible if the husband freezes the sperm during his life, but also in cases where the wife or a close family member requests that the sperm be taken after the husband's death (during the 24 hours after death, by the process of electro-ejaculation, semen can be frozen and used postmortem). The second situation of posthumous reproductive application is the freezing of the egg cells by a woman suffering from a disease, after whose death the frozen and then fertilized egg with her husband's sperm will be implanted in the womb of the woman carrying the baby (the surrogate mother). The third situation is that of the freezing of the embryo and implantation of it in the womb of another woman who will bear and give birth to the child after the death of the genetic parents (Selmani-Bakiu, 2020). Although this method is regulated by a positive law in the RNM, its implementation encountered many problems and legal contradictions. The child that will be born post-mortem, does not enjoy the inheritance rights like other children, because this child is not counted in the category of potential heirs according to the Inheritance Law Act of the RM. ${ }^{8}$ The next problem arises regarding the paternity of this child. In the event of the death of the husband, posthumous reproduction is permitted with his prior written consent, up to a maximum of 1 year after his death. If posthumous reproduction is applied and if the child is born after the death of the husband (for a period longer than 300 days), then that child will have the status of illegitimate child (according to the Family Law of the RM) due to the fact that the marriage has been seized with the actual death of one of the spouses. In this situation, in order to prove paternity, the procedure for recognizing paternity provided by the Law on Family must be developed (Selmani-Bakiu, 2020). Paternity of a child born out of marriage (in posthumous reproduction) can be accepted before the birth of the child and such an opportunity must be accompanied by legal provisions, with the sole purpose that these

life (the case nasciturus pro iam nato). Due to the fact that in posthumous reproduction the child is conceived after the decedent's death, he / she cannot be considered an heir. It is in no way acceptable to discriminate against children based on the time of conception. 
children do not have the problem of denying the biological identity.

From what was mentioned above, it can be clearly concluded that in the RNM are known and legally regulated all methods of artificial reproduction technology, methods that offer the opportunity to establish a family for all couples who on the biological way are prevented from doing the same. The Law on $\mathrm{BAF}$ is a well-concepted law which regulates in detail all aspects of the implementation of artificial reproduction procedures. The problem lies in the implementation of this law as well as its harmonization with international conventions and other positive laws of the country. The next problem lies in the principle of the best interest of the child which is not set as the main principle which must be respected during the implementation of these procedures.

\section{Assisted Reproductive Technology in Republic of Kosovo - Law on Reproductive Health}

Probably completely coincidental, but in the Republic of Kosovo as well as in the RNM, in 2008 for the first time we have a law which regulates artificial reproduction. Artificially assisted reproduction is regulated by the Law on Reproductive Health in Chapter V with only few articles, from Articles 18 to 26. First, it is important to note that the Law on Reproductive Health (RH) of Kosovo regulates organization, functioning and the supervision of all activities in the field of reproductive health, in the health institutions, and protects reproductive rights of individuals and couples, including also the right to be informed and to have the access to necessary services. Reproductive right is an individual and the couple's right to decide freely and with responsibility on the number, frequency and time when they want to have children, the access right to information, education, communication and instruments which will enable their decisions to be based on evidence (Law on RH, 2007, Article 2).

Pursuant to the Law on RH of Kosovo each individual, regardless of gender, ideological, religious or cultural orientation is guaranteed-ensured the right to information and education for sexual and reproductive health during all his/her life cycle. All persons and couples have the right, respecting wishes of each of the couples, to decide freely about the time, number and birth intervals and to be informed about necessary means for their realization. This Law guarantees to each individual the right to make a decision on realization of reproductive rights according to their free wish and interest without any discrimination, enforcement and violence. Reciprocal respect, understanding, personal integrity, indefeasibility and responsibilities sharing for sexual behaviors and their consequences are the female and male bilateral obligation (Article 4.1, 4.2, 4.3, 4.4). Sexual and reproductive health and rights are the state of complete physical, mental and social well-being which includes any condition pertaining to the reproductive system and which is not defined solely as the mere absence of disease, dysfunction or insufficiency. Reproductive health and rights are inseparable from the general well-being and proper development of each society. Currently in Kosovo the magnitude of the problem related to reproductive health cannot be accurately described due to lack of data from the Health Information System, lack of evidence, lack of reporting and payment for performance. These shortcomings are disabling the identification of the extent of the problem according to certain features such as: age, place of residence, gender, socio-economic status, etc. (Ministry of Health of the Republic of Kosovo, 2018).

Also, it is important to note that the Republic of Kosovo through its biomedical legislation within the framework of reproductive health enumerates some basic rights, such as: The reproductive right for individuals and couples to decide freely and responsibly on the number, frequency and time when they want to have children; The right to information and education throughout the life cycle; The right to safe motherhood so that every woman can receive the care she needs to be in good health from pregnancy to childbirth; The right to family planning which is the right of individuals and couples to be informed, to predict and to decide freely on the number, frequency and time when they wish to have children; The right to adequate prevention and treatment of infertility; The right to safe termination of pregnancy; The right to services for prevention and treatment of sexually transmitted infections, HIV/AIDS, as well as infections and diseases of the reproductive tract; The right to prevention, early detection and treatment of malignant diseases of the reproductive system and breast cancer (Coalition K10, 2017). Pursuant to the Law on RH assisted reproduction corresponds to free will and couple parental request to have a child and by treating the infertility medical causes or prevent transmission of diseases from parents to child. The assisted reproduction is used in cases when: other infertility treatment methods for a female, male or partners are not productive or suitable and do not guarantee a desired result; It is recommended for the prevention of parent to child transmission of genetic diseases; It is recommended for the prevention of transmission of other diseases which would result in a premature death, mental backwardness and or serious child disability; It is considered as the only alternative for childbirth (Article 18-20). The assisted reproduction includes the clinical and biological procedures, which enable: artificial insemination; in-vitro fertilization; transfer of embryos; other equivalent techniques, which allow reproduction out of natural process (Article 21). Prior to being subject to assisted reproduction, according to the 
Law for the citizens' rights and responsibilities in health care No. 2004/38, the beneficiary couple shall be informed about procedures success or failure; informed about mother and child's risks; evaluated for their motivation; informed about legal opportunities for a child adoption and address-refer to respective social institutions (Article 22). The prohibited activities in the assisted reproduction field are as follows: embryos abuse-misuse for commercial, industrial and experimental purposes; genetic manipulations in embryos; illegal embryos donations; gametes trafficking; gametes mixing; intermediate agreement for a substation maternity, post-mortem insemination without the prior partner's written consent; violence of the confidentiality data right on the gametes donator; selective abortion of embryos of the specific gender; child's gender selection, except to cases with health indications to mother and child (Article 23). Commission formed by the Ministry of Health for medical assisted reproduction will be responsible for activities coordination and supervision of the medical assisted reproduction). Authority and composition of the Commission for medical assisted reproduction will be determined by a sub-legal act (Article 24.1, 24.2) Conditions, requirements for use of the assisted reproduction technologies, artificial insemination and fertilization resulting with embryo's implantation will be determined by a sub-legal act (Article 25). All individuals and couples have the right to be informed about the risks, education and communication based on the evidence, free choice and benefit from use of safe means and methods, resistible and acceptable for family planning (Article 12). Advice providing services for family planning will be provided by health or social trained staff and at institutions, which offer confidentiality. It is the duty of the health or social employee at the health institutions to inform the individual or couple relating to family planning (Article 13.1, 13.2). Acceptable family planning methods and means will be determined by a sublegal act. Only specialists of gynecology and obstetrics and family doctors are allowed to prescribe contraceptives or recommend use of the means and medical contraceptive technologies (Article 14, 15).

From this it can be concluded that, in the Republic of Kosovo, the legal regulation of assisted reproduction is very deficient, and it is regulated within a legal text which regulates reproductive health in general. Given that the problems with infertility of young couples are increasing more and more, the opportunities that should be offered has to be greater. Information regarding the possibility of applying artificially assisted fertilization is very scarce and it affects the confidence of couples in applying these methods. The practice observes the situations of application of these methods in the nearest regional private hospitals in RNM and Turkey,
As can be seen in the Law on Reproductive Health, surrogacy is prohibited in the Republic of Kosovo as a way of establishing a family, i.e. a woman who has a congenital or acquired absence of a uterus or an anomaly born in the uterus which cannot be corrected with modern surgical procedures or has irreparable damage uterus or if the women has a congenital or acquired ovarian insufficiency or congenital ovarian anomalies that cannot be corrected with modern surgical procedures or has ovarian damage that cannot be cured, must agree with the fate of not having children. Regarding the post-mortem or posthumous reproduction, the Law on Reproductive Health is very vague in this regard. From Article 23 of the Law it can be concluded that posthumous reproduction is not allowed only without the written consent of the partner, which means that if there is consent, the other partner can give birth to the child after the death of the partner whose genetic material was previously frozen. The law in this regard is very vague and contradictory to the one that prohibits surrogacy while on the other hand does not specify which of the partners can freeze the genetic material and whether this right is recognized under the same conditions to the husband and woman. It should be clarified that if the freezing of genetic material (egg cell and sperm) and embryo is allowed, then posthumous reproduction should be allowed for both male and female partners, with that if the woman dies then the husband can give birth to the child with the frozen egg of the deceased woman through a carrying (surrogate) woman by in vitro process. Other details about this method of starting a family are not found in any document or any information with public character.

\section{Conclusion}

It is indisputable that new technologies for artificial reproduction have proved very useful for infertile couples who have managed to realize themselves as parents thanks to their application. The authors in this text provide all the details about the types of these methods and procedures for their implementation in the Republic of North Macedonia and the Republic of Kosovo, emphasizing the similarities and comparisons in these two countries. In both countries since 2008 we have laws that regulate these methods. Compared to the Republic of Kosovo, RNM has shown a more serious approach in this regard, because it has a sui generis law which regulates all methods of artificial reproduction and which law is considered as one of the most liberal laws in the region. On the other hand, Kosovo has a lot of work to do in this regard. As mentioned above, the Republic of Kosovo regulates artificial reproduction within the Law on Reproductive Health with a very small number of articles which are contradictory in the part of post-mortem reproduction. Given the need for many young couples who are constantly facing infertility and other reproductive health problems, Kosovo should initiate professional and public debates towards the incorporation of 
surrogacy as an opportunity to establish a family for all couples who do not succeed with other biomedical assisted fertilization methods. Finally, the Republic of Kosovo should work harder to promote the rights of artificial reproduction for couples who cannot establish a family in a biological way. Although RNM has a very liberal law, it faces problems of legal contradictions, nonharmonization of the Law Family Act with the UN Convention on the Rights of the Child and the European Convention on Human Rights in terms of non-recognition of the right of the child born through artificial methods to obtain information about their biological origin and other legal gaps which are mentioned in detail by the authors in this text. The authors are of the opinion that with the dynamics in which family processes are changing in these two countries, laws should provide greater opportunities for establishment of parenthood. Laws need to be more liberal, clearer and serve as solutions to the everyday problems that people face. The main principles on which family law should be based are the protection of privacy, family life, equal treatment of the positive right to reproduction as well as the negative right to reproduction, with the sole purpose that every born child is desired by his parents.

\section{References}

1. Lewis, M.A., \& Tamparo, C.D. (2007). Medical law, ethics, and bioethics for the health professions (6th ed). Philadelphia. A. Davis Company, (Chapter 1).

2. Mickovik,D., Ignovska,E., Ristov,A. (2016). Новите репродуктивни технологии и правото. Skopje: Ss. Cyril and Methodius University, (Chapter 2).

3. Raymond, J.G. (1993). Women as wombs: Reproductive Technologies and the Battle Over Women's Freedom. North Melbourne: Spinifex Press Pty Ltd, (Introduction).

4. Riley, L. (2015). The 'three parent' misnomer: Mitochondrial DNA donation under the HFE Act. In K. Horsey (Eds.), Revisiting the Regulation of Human Fertilisation and Embryology (pp. 98-116). New York: Routledge.

5. Robertson, JA. (1994). Children of choice: freedom and the new reproductive technologies. New Jersey: Princeton University Press, (Chapter 1).

6. Sanger, A. (2004). Beyond choice: Reproductive Freedom in the 2ist century. New York: Public Affairs TM. (Chapter 3).

7. Selmani-Bakiu, A. (2016). Стекнување на родителското право преку сурогат мајка- посебен осврт на Законот за изменување и дополнување на законот за биомедициснко потпомогнато оплодување, Proceedings of Third International scientific conference Social change in the global world- Center for Legal and Political Research, pp. 129-152, Faculty of Law, Goce Delcev University, 2016 September. Stip: Center for Legal and Political Research

8. Selmani-Bakiu, A. (2020). Posthumous Reproduction: Legal Status of the Child and Contradictions of Legal Norms in the National Legislation of RNM. Proceedings of International Conference Good Governance and the Rule of Law in the Perspective of EU Integration, pp. 611-625. Skopje, Republic of Macedonia, 2019, September, Skopje: South East European University.

9. Zendeli,E., Selmani-Bakiu,A., Mickovik, D., Ristov,A. (2020). E drejta familjare. Tetovo: Arberia Design, (Chapter 2).

10. American Society for Reproductive Medicine. (2018). Assisted Reproductive Technology- A Guide for Patients. [Online] Available: https://www.reproductivefacts.org/globalassets/rf/ne ws-and-publications/bookletsfact-sheets/english-factsheets-and-info-booklets/art-booklet2.pdf [Accessed, 20 November, 2020].

11. American Society for Reproductive Technology. (2020). Assisted Reproductive Technologies. [Online] Available: https://www.asrm.org/topics/topicsindex/assisted-reproductive-technologies/ [Accessed, 20 November, 2020].

12. Family Law Act of Republic of Macedonia. (1992). (Consolidate Version, 2015). [Online] Available: http://www.slvesnik.com.mk/

13. Human Fertilization and Embryology Authority. (2020). Mitochondrial donation treatment. [Online] Available:

https://www.hfea.gov.uk/treatments/embryo-testingand-treatments-for-disease/mitochondrial-donationtreatment/ [Accessed, 28 November, 2020].

14. Inheritance Law Act, Official Gazette of RM, no.47/1996. [Online] Available: https://www.akademika.com.mk/

15. International Conference on Population and Development Programme of Action, Twentieth Anniversary Edition, (2014). [Online] Available: https://www.unfpa.org/sites/default/files/pubpdf/programme of action Web\%20ENGLISH.pdf [Accessed, 24 November, 2020].

16. Law no.02/L-76 on Reproductive Health of Kosovo. (2007). [Online] Available: http://www.gazetazyrtare.com/egov/index.php?optio 


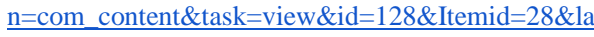
$\underline{\mathrm{ng}=\mathrm{en}}$

17. Law on Biomedical Assisted Fertilization (Consolidate Version). Official Gazette of RMV no. 37/2008, 164/2013, 149/2014, 192/2015 and 37/2016). [Online] Available: https://www.akademika.com.mk/

18. Selmani-Bakiu,A. (2016). Të lindësh për dikë fëmijën e porositur! [Online] Available: http://www.time.al/Selmani-Te-lindish-per-dikefemijen-e-porositur-/Te-lindesh-per-dike-femijen-eporositur-.aspx [Accessed, 29 November, 2020].

19. Selmani - Bakiu,A. (2018). Lindja e fëmijës postmortem. [Online] Available: https://portalb.mk/571909-lindja-e-femijes-postmortem/ [Accessed, 01 December, 2020].

20. Selmani-Bakiu,A. (2020). Dita ndërkombëtare e bioetikës dhe teknologiia për reprodukim artificial. [Online] Available:

https://blog.seeu.edu.mk/2020/10/19/dita-

nderkombetare-e-bioetikes-dhe-teknologjia-perreprodukim-artificial/ [Accessed, 27 November, 2020].

21. Selmani-Bakiu, A. (2020). Dita ndërkombëtare e familjes dhe gjendja aktuale në legjislacionin familjarë të Republikës së Maqedonisë së Veriut. [Online] Available: https://blog.seeu.edu.mk/2020/05/15/15-maj-ditanderkombetare-e-familjes-dhe-gjendja-aktuale-nelegjislacionin-familjare-te-republikes-semaqedonise-se-veriut/ [Accessed, 15 November, 2020].

22. The European Convention on Human Rights (1950). [Online] Available: https://www.echr.coe.int/Documents/Convention_EN G.pdf

23. UN Convention on the Rights of the Child (1989). [Online] Available: https://www.ohchr.org/en/professionalinterest/pages/ crc.aspx

24. Universal Declaration of Human Rights (1948). [Online] Available: https://www.un.org/en/universaldeclaration-human-rights/

25. World Health Organization Maternal Health and Safe Motherhood Programme. (1995) . Achieving Reproductive Health for all World Health Organization. [Online] Available: https://apps.who.int/iris/handle/10665/63717 [Accessed, 03 December, 2020].
26. Koncept dokument për fushën e shëndetit riprodhues dhe fertilizimin e asistuar. Ministry of Health of Kosovo, (2018). [Online] Available: http://kryeministri-ks.net/wpcontent/uploads/2018/12/Koncept-Dokumentip\%C3\%ABr-Fush\%C3\%ABn-e-Sh\%C3\%ABndetitRiprodhues-dhe-Fertilizimin-e-Asistuar-MSH-Shqip1.pdf [Accessed, 15 November, 2020].

27. Koalicioni K10, (2017). [Online] Available: http://www.k10-ks.org/te-drejtat/legjislacioni [Accessed, 01 December, 2020].

28. United Nations Population Fund, (1969). UNFPA. [Online] Available: https://www.unfpa.org/familyplanning [Accessed, 01 December, 2020]. 